\title{
PENGARUH BIAYA BAURAN PROMOSI TERHADAP OMZET PENJUALAN USAHA AGRIBISNIS DI DENPASAR
}

\author{
The Influence of Promotion Mix Cost Toward Sales Turnover of \\ Agribusiness in Denpasar
}

\author{
Putu Evi Henda Niri Antari, Ketut Budi Susrusa, Ketut Suamba
}

Program Studi Magister Agribisnis, Fakultas Pertanian, Universitas Udayana, Bali, Indonesia

Email:evihedal@gmail.com

\begin{abstract}
Marketing requires more than just developing a good product, set an attractive price, offering an affordable prices, but also need to promote the product itself. The success of a marketing program also determined by promotion mix. This research aimed to analyzed the influence of promotion mix cost simultaneously, partially and the most dominantly variable toward the sales turnover of agribusiness company in Denpasar. The research method was used descriptive statistics. Through descriptive statistical analysis will be described and described characteristic table of respondents, while the influence of promotion mix cost to sales turnover using multiple linear regression analysed using the help of SPSS program version 22.0. Based on multiple linear analysis, the results of research showed promotion mix variables give simultaneous positive and significant effect toward the sales turnover $p \leq 0.05$ with determination coefficient 0.575 or $57.5 \%$. Partially, all of five variables promotional mix showed that the cost of advertising, cost of personal selling, cost of sales promotion and cost of direct marketing give significant affect, while the variable cost of public relations showed insignificant results. The most dominant variable affecting the sales turnover is the cost of sales promotion with standardized beta coefficient point to 0.463. Suggestions that can be given by the author to agribusiness entrepreneurs in Denpasar in order to implement promotional mix cost policies that are appropriate in the future to be in accordance with the capabilities and budget owned by the company. The combination of the five components of the promotional mix costs is still carried out, but must pay attention and consider allocating funds efficiently into the promotional mix costs so that the company does not experience losses.
\end{abstract}

Key words: marketing, promotion mix, sales turnover

\begin{abstract}
ABSTRAK
Pemasaran membutuhkan lebih dari sekedar mengembangkan produk yang baik, menetapkan harga yang menarik, menawarkan harga yang terjangkau, tetapi juga perlu mempromosikan produk itu sendiri. Keberhasilan program pemasaran juga ditentukan oleh bauran promosi. Penelitian ini bertujuan untuk menganalisis pengaruh biaya bauran promosi secara simultan, parsial dan variabel yang paling dominan terhadap omset penjualan perusahaan agribisnis di Denpasar. Metode penelitian menggunakan statistik deskriptif. Melalui analisis statistik deskriptif akan diuraikan dan diuraikan tabel karakteristik responden, sedangkan pengaruh biaya bauran promosi terhadap omset penjualan dianalisis menggunakan regresi linier berganda menggunakan bantuan program SPSS versi 22.0. Berdasarkan analisis linier berganda, hasil penelitian menunjukkan variabel bauran promosi memberikan pengaruh positif dan signifikan secara simultan terhadap omset penjualan $\mathrm{p} \leq 0,05$ dengan koefisien determinasi 0,575 atau 57,5\%. Secara parsial, kelima variabel bauran promosi menunjukkan bahwa biaya iklan, biaya penjualan pribadi, biaya promosi penjualan dan biaya pemasaran langsung memberikan pengaruh yang signifikan, sedangkan biaya variabel hubungan masyarakat menunjukkan hasil yang tidak signifikan. Variabel yang paling dominan mempengaruhi omset penjualan adalah biaya promosi penjualan dengan titik koefisien beta terstandarisasi menjadi 0,463. Saran yang dapat diberikan oleh penulis kepada wirausaha agribisnis di Denpasar agar dapat menerapkan kebijakan bauran promosi yang sesuai di masa depan agar sesuai dengan kemampuan dan anggaran yang dimiliki oleh perusahaan. Kombinasi dari lima komponen biaya bauran promosi masih dilakukan, tetapi harus memperhatikan dan mempertimbangkan mengalokasikan dana secara efisien ke dalam biaya bauran promosi sehingga perusahaan tidak mengalami kerugian.
\end{abstract}

Kata kunci: pemasaran, bauran promosi, omset penjualan 


\section{PENDAHULUAN}

\section{Latar Belakang}

Denpasar sebagai Ibu Kota Provinsi Bali merupakan pusat perdagangan, jasa, pendidikan dan pariwisata. Denpasar sebagai Ibu Kota tentu banyak potensipotensi yang bisa dikembangkan untuk menuju pembangunan ke arah yang lebih baik. Potensi unggulan lainnya yang dimiliki Kota denpasar adalah disektor pertanian dengan luas lahan $12.778 \mathrm{Ha}$ dan luas lahan sawah 2.717 Ha masih memiliki peluang atau potensi untuk mengembangkan pertanian pangan (Http://st2013.bps.go.id). Produk- produk unggulan hasil pertanian diproduksi oleh usaha Mikro, Kecil dan Menengah (UMKM). Saat ini UKM Kota Denpasar jenis usaha industri pertanian jumlah total 16.727 yang terdiri dari usaha Mikro 16.098, usaha Kecil 144 dan usaha Menegah sebanyak 148 buah (http://ukmdiskop.denpasarkota.go.id).

Menurut Kotler dan Armstrong (2012) promosi merupakan kegiatan yang mengomunikasikan manfaat dari sebuah produk dan membujuk target konsumen untuk membeli produk tersebut. Senada dengan pendapat Swasta dan Irawan (2008) mengungkapkan promosi adalah arus informasi atau persuasi satu arah yang dibuat untuk mengarahkan seseorang atau organisasi kepada tindakan yang menciptakan pertukaran dalam pemasaran. Menurut Dane (2012) salah satu faktor penentu keberhasilan suatu pogram pemasaran adalah promosi. Promosi merupakan bermacam kegiatan yang dapat dilakukan perusahaan untuk mengkomunikasikan kelebilan- kelebihan produknya dan membujuk pelanggan sasaran untuk membeli produk yang dihasilkan. Kegiatan pemasaran dan promosi perusahaan ketika berjalan dengan baik dan dapat menarik minat konsumen, maka otomatis penjualan pun akan ikut meningkat, tetapi yang menjadi masalah adalah seringkali kegiatan promosi ada yang tidak efektif dan hanya membuat pengeluaran perusahaan mengalami pembengkakan. Oleh karena itu, diperlukan penelitian untuk mengetahui pengaruh biaya bauran promosi terhadap omzet penjualan usaha agribisnis di Denpasar.

\section{Tujuan Penelitian}

adanya pengaruh biaya bauran promosi yang terdiri atas biaya periklanan, biaya promosi penjualan, biaya penjualan perorangan, biaya hubungan masyarakat dan biaya pemasaran langsung secara simultan, parsial dan yang berpengaruh dominan terhadap omzet penjualan pada usaha agribisnis di Denpasar

\section{METODE PENELITIAN}

\section{Lokasi dan Waktu Penelitian}

Penelitian ini dilaksanakan di Kota Denpasar, sedangkan waktu penelitian dilakukan pada bulan Maret s.d Mei 2018. Pemelihan lokasi penelitian ditentukan dengan cara sengaja (purposive) dengan pertimbangan Denpasar sebagai Ibu Kota Provinsi Bali yang merupakan pusat perdagangan, kerajinan, pariwisata dan pendidikan.

\section{Populasi dan Sampel}

Populasi merupakan totalitas dari semua objek atau individu yang memiliki karakteristik tertentu, jelas dan lengkap yang akan diteliti (Hasan, 2002). Objek atau nilai yang diteliti dalam populasi disebut unit analisis atau elemen populasi yang dapat berupa orang, perusahaan, media, dan sebagainya. Dalam penelitian ini, populasi yang digunakan adalah pelaku usaha agribisnis yang melakukan bauran promosi sebanyak 44 buah.

Menurut Sugiyono (2015) sampel adalah bagian dari jumlah dan karakteristik yang dimiliki oleh populasi tersebut, bila populasi besar dan penelitian tidak mungkin mempelajari semua yang ada pada populasi, misal keterbatasan dana, tenaga dan waktu maka peneliti dapat menggunakan sampel yang diambil dari populasi, untuk itu sampel yang diambil dari populasi harus betul- betul representatif (mewakili). Teknik sampling yang digunakan untuk menentukan jumlah masingmasing sampel dalam penelitian ini adalah teknik sampling nonprobabilitas yaitu sampling jenuh atau sensus, di mana semua anggota populasi sebanyak 44 pelaku usaha dijadikan sampel.

\section{Variabel Penelitian dan Teknik Pengumpulan Data}

Variabel yang digunakan untuk menganalisis yaitu variabel bebas antara lain biaya periklanan (X1), biaya promosi penjulanan (X2), biaya penjualan perorangan (X3), biaya hubungan masyarakat dan publisitas (X4), biaya pemasaran langsung (X5), dan variabel terikat yaitu omzet penjualan $(\mathrm{Y})$. Teknik pengumpulan data dilakukan dengan beberapa metode, yaitu.

1. Wawancara (interview)

Wawancara dilaksanakan dengan cara mengadakan tanya jawab langsung kepada bagian pemasaran, produksi, dan pemilik perusahaan yang memberikan keterangan berupa biaya-biaya promosi yang dikeluarkan setiap tahun meliputi biaya periklanan, biaya penjualan perorangan, biaya promosi penjualan, biaya hubungan masyarakat dan biaya pemasaran langsung serta omzet penjualan tiap tahunnya.

2. Dokumentasi

Dokumentasi dilaksanakan dengan cara mencatat dan mengolah dokumen yang berupa catatan-catatan, arsip-arsip, maupun laporan-laporan yang dimiliki oleh perusahaan. Catatan maupun arsip yang akan diolah berupa pengeluaran biaya promosi maupun omzet penjualan dalam satuan rupiah selama satu tahun.

3. Kuisioner

Kuisioner adalah sejumlah pertanyaan tertulis yang digunakan untuk untuk memperoleh imformasi dari responden dalam arti laporan tentang pribadinya 
atau hal-hal yang diketahui yang berkaitan dengan penelitian kuisioner ini akan ditujukan kepada responden- responden yang memiliki keterkaitan dengan data penelitian yang dicari oleh peneliti. Responden yang dimaksud adalah pelaku usaha bergerak bidang agribisnis yang melakukan bauran promosi di Kota Denpasar yaitu pimpinan, bagian pemasaran dan karyawan perusahaan akan dijadikan sebagai responden kunci yang jawabanya dianggap paling tepat dan benar.

\section{Metode analisis Data}

Data yang dikumpulkan akan dianalisis dengan analisis statistik deskriptif. Melalui analisis statistik deskriptif akan diuraikan dan digambarkan dengan tabel karakteristik responden ditinjau dari variabel demografinya seperti tingkat pendidikan, umur dan jenis kelamin. Sedangkan besar pengaruh biaya bauran promosi terhadap omzet penjualan menggunakan analisis regresi linear berganda. Pengolahan data menggunakan bantuan program SPSS versi 22.0. Sebelum model regresi digunakan, maka terlebih dahulu dilakukan pengujian asumsi klasik.

\section{Uji Asumsi Klasik}

\section{a. Uji Normalitas}

Uji normalitas dilakukan untuk menguji sebuah model regresi variabel dependen, indefenden atau keduanya telah berdistribusi normal atau tidak. Model regresi yang baik adalah yang memiliki distribusi normal atau mendekati normal. Uji asumsi klasik pengujian normalitas dilakukan dengan menggunakan pengujian grafik P-P Plot untuk pengujian residual model regresi (Widarjono, 2015).

\section{b. Uji Multikolinieritas}

Uji multikolinieritas dimaksudkan untuk membuktikan atau menguji ada atau tidaknya hubungan yang linier (multikolinieritas) antara variabel bebas (independent) satu dengan variabel bebas yang lain. Untuk mengetahui antara variabel bebas satu dengan variabel bebas yang lain tidak terjadi multikolinieritas jika Varian Inflatation Factor (VIF) kurang dari 10 dan angka Tolernce lebih dari 0,1 .

\section{c. Uji Heterokedastisitas}

Uji heterokedastisitas dilakukan untuk mengetahui bahwa pada model regresi terjadi ketidaksamaan varian. Cara mendeteksinya adalah dengan melihat ada tidaknya pola tertentu pada grafik scatterplot antara SRESID dan ZPRED, dimana sumbu Y adalah Y yang telah diprediksi, dan sumbu $\mathrm{X}$ adalah residual ( $\mathrm{Y}$ prediksi $-\mathrm{Y}$ sesungguhnya) yang telah standardized.

\section{Analisis regresi linier berganda}

Adapun analisis yang digunakan dalam penelitian ini adalah analisis regresi berganda. Dengan menggunakan perumusan sebagai berikut.

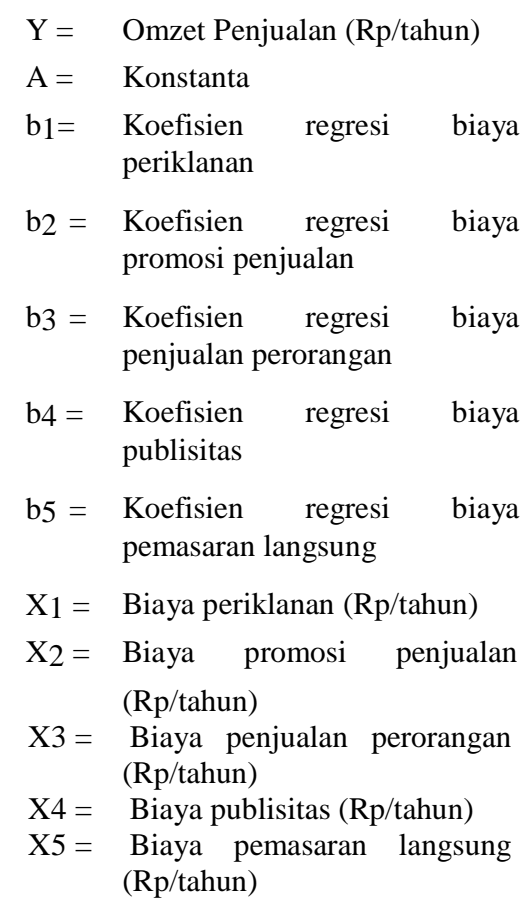

Uji F

Uji F digunakan untuk menguji pengaruh dari seluruh variabel independent secara bersama- sama terhadap variabel dependent. Uji $F$ juga bisa dengan membandingkan Fhitung dengan Ftabel, apabila Fhitung $>$ Ftabel maka $\mathrm{H} 0$ ditolak dan $\mathrm{H} 1$ diterima.

\section{Uji t (t test)}

Uji t digunakan untuk menguji pengaruh dari seluruh variabel independent secara parsial terhadap variabel dependent. Pada uji t, nilai thitung akan dibandingkan dengan nilai tabel, apabila thitung $>$ tabel maka $\mathrm{H}_{0}$ ditolak dan $\mathrm{H} 1$ diterima.

\section{Standardized coefficient beta}

Pengujian dominasi variabel bebas terhadap variabel terikat akan digunakan dengan melihat pada Standardized coefficient beta. Nilai Standardized coefficient beta yang paling tinggi akan menunjukkan pengaruh dominan terhadap variabel terikat.

\section{HASIL DAN PEMBAHASAN}

\section{Karakteristik Responden}

Dengan adanya karakteristik responden diharapkan dapat mengungkapkan informasi mengenai gambaran keadaan sampel penelitian, khususnya menyangkut variabel demografis responden seperti umur, tingkat pendidikan, jenis kelamin, jenis usaha dan umur perusahaan.

\section{Umur}

Karakteristik responden berdasarkan kelompok umur dalam penelitian ini, dapat dijelaskan melalui Tabel 1. 
Tabel 1. Karakteristik Responden Berdasarkan kelompok

\begin{tabular}{cccc} 
Umur & & \\
\hline No & $\begin{array}{c}\text { Umur } \\
\text { (tahun) }\end{array}$ & $\begin{array}{c}\text { Frekuensi } \\
\text { (orang) }\end{array}$ & $\begin{array}{c}\text { Persentase } \\
(\%)\end{array}$ \\
\hline 1 & $25-34$ & 8 & 18,2 \\
2 & $35-44$ & 22 & 50,0 \\
3 & $45-54$ & 8 & 18,2 \\
4 & $55-64$ & 6 & 13,6 \\
\hline & Jumlah & 44 & 100,00 \\
\hline
\end{tabular}

Sumber: Data primer diolah (2018)

Responden terbanyak berada pada kelompok umur 3544 tahun yaitu sebanyak 22 orang atau sebesar $50 \%$. Kondisi ini menunjukkan bahwa secara umum jika dilihat dari umur para responden, responden berada pada kelompok usia masih produktif, yaitu usia dimana kemampuannya menunjukkan produktivitas kerja masih sangat baik dan potensial dalam mengembangkan usahanya.

\section{Tingkat Pendidikan}

Karakteristik responden ditinjau berdasarkan tingkat pendidikan, dapat dilihat pada Tabel 2.

Tabel 2. Karakteristik Responden Berdasarkan Tingkat Pendidikan

\begin{tabular}{llcc}
\hline No & Pendidikan & $\begin{array}{c}\text { Frekuensi } \\
\text { (orang) }\end{array}$ & $\begin{array}{c}\text { Persentase } \\
(\%)\end{array}$ \\
\hline 1 & SMA & 17 & 38,6 \\
2 & Diploma & 1 & 2,3 \\
3 & S1 & 24 & 54,5 \\
4 & S2 & 1 & 2,3 \\
5 & S3 & 1 & 2,3 \\
\hline & Jumlah & 44 & 100 \\
\hline
\end{tabular}

Sumber: Data primer diolah (2018)

Tingkat pendidikan sebagaian besar atau dominan adalah S1 sebanyak 24 responden (54,5\%), SMA sebanyak 17 responden $(38,6 \%)$, Diploma 1 responden (2,3\%), S2 sebanyak 1 responden (2,3\%) dan S3 sebanyak 1 responden $(2,3 \%)$. Kondisi ini menunjukkan bahwa tingkat pendidikan responden dalam penelitian ini pada umumnya sangat memadai. Tingkat pendidikan yang memadai dapat memudahkan dalam pengambilan keputusan di bidang bauran promosi yang tepat dalam pengembangan usaha agribisnis.

\section{Jenis Kelamin}

Karateristik responden berdasarkan jenis kelamin dalam penelitian ini, dapat dilihat pada Tabel 3 .

Tabel 2. Karakteristik Responden Berdasarkan Tingkat Jenis Kelamin

\begin{tabular}{llcc}
\hline No & Jenis Kelamin & $\begin{array}{c}\text { Frekuensi } \\
\text { (orang) }\end{array}$ & $\begin{array}{c}\text { Persentase } \\
(\%)\end{array}$ \\
\hline 1 & Laki-laki & 30 & 68,2 \\
2 & Perempuan & 14 & 31,8 \\
\hline & Jumlah & 44 & 100 \\
\hline
\end{tabular}

Sumber: Data primer diolah (2018)

Perbedaan pada jumlah jenis kelamin responden laki-laki sebanyak 30 atau sebesar $(68,2 \%)$ dan perempuan sebanyak 14 orang atau sebesar
$(31,8 \%)$ yang mana responden laki-laki lebih mendominasi dibandingan jumlah responden perempuan.

\section{Jenis Usaha}

Karateristik responden berdasarkan jenis usaha dalam penelitian ini, dapat dilihat pada Tabel 4.

Tabel 4. Karakteristik Responden Berdasarkan Jenis Usaha

\begin{tabular}{|c|c|c|c|c|}
\hline No & Kecamatan & $\begin{array}{c}\text { Jenis } \\
\text { usaha }\end{array}$ & $\begin{array}{c}\text { Frekuensi } \\
\text { (Buah) }\end{array}$ & $\begin{array}{l}\text { Persen- } \\
\text { tase }(\%)\end{array}$ \\
\hline 1 & $\begin{array}{l}\text { Denpasar } \\
\text { Barat }\end{array}$ & $\begin{array}{l}\text { Makanan, } \\
\text { buah dan } \\
\text { sayur, aroma } \\
\text { terapi }\end{array}$ & 13 & 29,5 \\
\hline 2 & $\begin{array}{l}\text { Denpasar } \\
\text { Utara }\end{array}$ & $\begin{array}{l}\text { Makanan, } \\
\text { tanaman (bibit } \\
\text { buah), buah } \\
\text { dan sayur }\end{array}$ & 4 & 9,1 \\
\hline 3 & $\begin{array}{l}\text { Denpasar } \\
\text { Timur }\end{array}$ & $\begin{array}{l}\text { Obat herbal, } \\
\text { tanaman hias, } \\
\text { bibit buah, } \\
\text { aroma terapi, } \\
\text { buah dan } \\
\text { sayur }\end{array}$ & 9 & 20,5 \\
\hline 4 & $\begin{array}{l}\text { Denpasar } \\
\text { Selatan }\end{array}$ & $\begin{array}{l}\text { Obat herbal, } \\
\text { minuman, } \\
\text { makanan, } \\
\text { tanaman hias, } \\
\text { dan aroma } \\
\text { terapi }\end{array}$ & 18 & 40,9 \\
\hline & Jumlah & & 44 & 100,00 \\
\hline
\end{tabular}

Sumber: Data primer diolah (2018)

Berdasarkan jenis usaha jumlah usaha agribisnis sebagai responden di Denpasar Selatan sebanyak 18 buah atau sebesar $(40,9 \%)$, Denpasar Barat sebanyak 13 buah atau sebesar 29,5\%, Denpasar Utara sebanyak 4 buah atau sebesar 9,1\% dan Denpasar Timur sebesar 9 buah atau sebesar $20,5 \%$. Berdasarkan data tersebut dapat disimpulkan bahwa sebagian besar responden usaha agribisnis dalam penelitian ini adalah di Denpasar Selatan dengan jenis usaha makanan, minuman, aroma terapi, dan tanaman hias.

\section{Umur Perusahaan}

Karakteristik responden berdasarkan kelompok umur perusahaan dalam penelitian ini, dapat dijelaskan melalui Tabel 5. 
Tabel 5. Karakteristik Responden Berdasarkan Umur Perusahaan

\begin{tabular}{cccc}
\hline No & $\begin{array}{c}\text { Umur } \\
\text { (Tahun) }\end{array}$ & $\begin{array}{c}\text { Frekuensi } \\
\text { (Buah) }\end{array}$ & $\begin{array}{c}\text { Persentase } \\
(\%)\end{array}$ \\
\hline 1 & $1-5$ & 13 & 29,5 \\
2 & $6-10$ & 17 & 38,6 \\
3 & $11-15$ & 9 & 20,5 \\
4 & $16-20$ & 4 & 9,1 \\
5 & $21-25$ & 1 & 2,3 \\
\hline
\end{tabular}

Sumber: Data primer diolah (2018)

Berdasar Tabel 5.5 dapat dilihat bahwa responden terbanyak berada pada kelompok umur perusahaan 6-10 tahun yaitu sebanyak 17 buah atau sebesar $38,6 \%$ pada bidang usaha makanan, buah dan sayur, aroma terapi, obat herbal, tanaman hias dan tanaman bibit buah. Umur perusahaan adalah lamanya sebuah perusahaan berdiri, berkembang dan bertahan. Sebuah perusahaan dapat dikatakan sukses apabila telah berumur 6-10 tahun, perusahan tersebut tetap berdiri bahkan terus berkembang, semakin lama umur perusahaan berdiri, semakin banyak pengalaman yang diperoleh dan kepercayaan konsumen terhadap produk-produk perusahaan tersebut.

\section{Uji Asumsi Klasik}

\section{Uji Multikolinieritas}

Model regresi dikatakan terbebas dari multikolinieritas apabila masing- masing variabel bebas memiliki Tolerance dan Variance Inflation Factor (VIF) tidak lebih dari 10 dan nilai Tolerance tidak kurang dari 0.1. Hasil uji multikolinieritas dapat dilihat pada Tabel 6 .

Tabel 6. Hasil Uji Multikolinieritas

\begin{tabular}{|c|c|c|c|}
\hline $\begin{array}{c}\text { Variabel } \\
\text { bebas }\end{array}$ & $\begin{array}{c}\text { Nilai } \\
\text { toleran } \\
\text { si }\end{array}$ & $\begin{array}{l}\text { Nilai } \\
\text { VIF }\end{array}$ & $\begin{array}{c}\text { Keterang } \\
\text { an }\end{array}$ \\
\hline $\begin{array}{l}\text { Biaya } \\
\text { periklanan } \\
(\mathrm{X} 1)\end{array}$ & 0,287 & 3,479 & $\begin{array}{l}\text { Nonmulti } \\
\text { kol }\end{array}$ \\
\hline $\begin{array}{l}\text { Biaya } \\
\text { promosi } \\
\text { penjualan } \\
\text { (X2) }\end{array}$ & 0,239 & 4,187 & $\begin{array}{l}\text { Nonmulti } \\
\text { kol }\end{array}$ \\
\hline $\begin{array}{l}\text { Biaya } \\
\text { penjualan } \\
\text { perorangan } \\
\text { (X3) }\end{array}$ & 0,203 & 4,929 & $\begin{array}{l}\text { Nonmulti } \\
\text { kol }\end{array}$ \\
\hline $\begin{array}{l}\text { Biaya } \\
\text { publisitas } \\
\text { (X4) }\end{array}$ & 0,396 & 2,525 & $\begin{array}{l}\text { Nonmulti } \\
\text { kol }\end{array}$ \\
\hline $\begin{array}{l}\text { Biaya } \\
\text { pemesanan } \\
\text { langsung } \\
\text { (X5) }\end{array}$ & 0,363 & 2,739 & $\begin{array}{l}\text { Nonmulti } \\
\text { kol }\end{array}$ \\
\hline
\end{tabular}

Sumber: Data Primer Diolah (2018)

Berdasarkan Tabel 6 diatas dapat dilihat bahwa besar nilai Variance Inflation Factor (VIF) dari biaya periklanan, biaya promosi penjualan, biaya penjualan perorangan, biaya hubungan masyarakat dan biaya pemasaran langsung tidak lebih dari 10 yaitu:
3,479, 4,187, 4,929, 2,525 dan 2,739 sedangkan besar nilai Tolerance biaya periklanan, biaya promosi penjualan, biaya penjualan perorangan, biaya hubungan masyarakat dan biaya pemasaran langsung tidak kurang dari 0,1 yaitu: 0,287, 0,239, 0.203 , 0,396 dan 0,365 jadi dapat dikatakan bahwa model regresi ini bebas dari asumsi klasik multikolinieritas.

\section{Uji Heteroskedastisitas}

Uji heteroskedastisitas dilakukan untuk menguji terjadinya perbedaan variance residual suatu periode pengamatan ke pengamatan periode berikutnya (Widarjono,

2015). Berikut ini hasil uji heteroskedastisitas pada Gambar 1 di bawah ini.

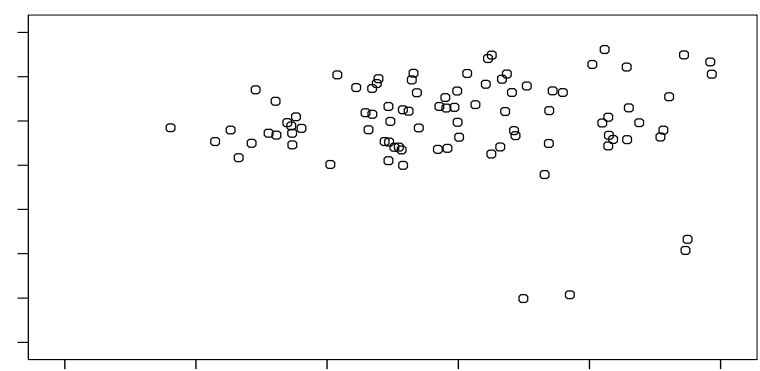

Gambar 1. Uji Heteroskedastisitas

Berdasarkan hasil uji heteroskedastisitas pada Gambar 1 di atas, dapat dilihat bahwa penyebaran titik-titik sudah memenuhi syrat yang diajukan, jadi dapat dikatakan bahwa model ini terbebas dari asumsi klasik heteroskedastisitas.

\section{Uji Normalitas}

Uji normalitas bertujuan untuk menguji apakah data variabel bebas dan variabel terikat pada persamaan regresi yang dihasilkan berdistribusi normal atau berdistribusi tidak normal. Cara menguji normalitas dari residual kita perlu memperhatikan grafik normal probability plot Agus Widarjono, (2015). Berikut diasjikan hasil uji normalitas data pada Gambar 2 di bawah ini.

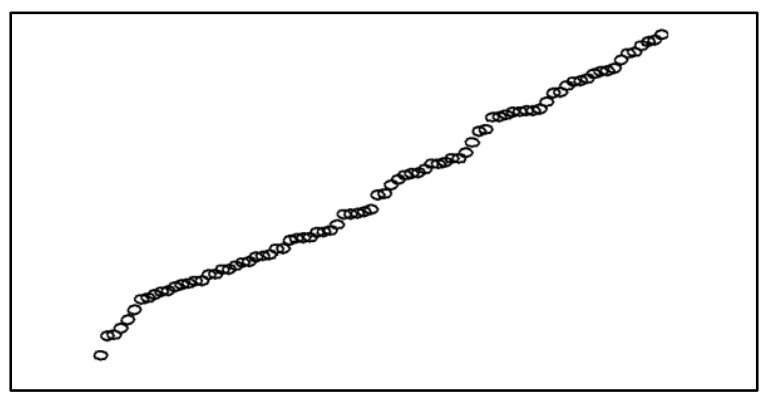

Gambar 2. Uji Normalitas Data dengan Normal P-Plot 
Berdasarkan Gambar 2 di atas, hasil uji normal p-plot of variable omzet penjualan, biaya periklanan, biaya promosi penjualan, biaya penjualan perorangan, biaya hubungan masyarakat dan biaya pemasaran langsung memperlihatkan bahwa distribusi dan titik-titik data menyebar di sekitar garis diagonal dan penyebaran titik-titik data searah dengan garis diagonal, jadi dari hasil uji normalitas data dapat dikatakan bahwa data yang digunakan dalam penelitian ini telah memenuhi syarat uji normalitas data.

\section{Hasil Analisis Regresi Linier Berganda}

Analisis linier berganda ini digunakan untuk mengetahui pengaruh biaya periklanan, biaya promosi penjualan, biaya penjualan perorangan, biaya publisitas dan biaya pemasaran langsung terhadap omzet penjualan usaha agribisnis di Denpasar. Analisis linier berganda ini mengunakan bantuan SPSS Release Version 22,0. Berikut ini disajikan hasil linier berganda pada Tabel 7.

Tabel 7.Hasil Analisis Regresi Linier Berganda

\begin{tabular}{cccccccc}
\hline Variabel & $\begin{array}{c}\text { Adju } \\
\text { sted }\end{array}$ & $\begin{array}{c}\text { Unstan } \\
\text { dardize }\end{array}$ & $\begin{array}{c}\text { standar } \\
\text { dized }\end{array}$ & F & Sig & T & Sig \\
& R & d & Coefici & & & & \\
& squa & Coefici & ent & & & & \\
re & ent & & & & &
\end{tabular}

\begin{tabular}{|c|c|c|c|c|c|c|c|}
\hline (Constant) & .575 & 15.539 & & 7.700 & .000 & 7.819 & .000 \\
\hline $\begin{array}{l}\text { Periklanan } \\
\text { (X1) }\end{array}$ & & .021 & .042 & & & $2.285^{*}$ & .018 \\
\hline $\begin{array}{l}\text { Promosi } \\
\text { penjual } \\
\text { an }(\mathrm{X} 2)\end{array}$ & & 149 & .463 & & & $2.906^{*}$ & .002 \\
\hline $\begin{array}{l}\text { Penjual } \\
\text { an } \\
\text { perorang } \\
\text { an (X3) }\end{array}$ & & .175 & .367 & & & $2.027 *$ & .043 \\
\hline $\begin{array}{l}\text { Hubung } \\
\text { an } \\
\text { masyara } \\
\text { kat (X4) }\end{array}$ & & 0.65 & .121 & & & $.833^{\mathrm{ns}}$ & .407 \\
\hline $\begin{array}{l}\text { Pemasar } \\
\text { an } \\
\text { langsung } \\
\text { (X5) }\end{array}$ & & 1.45 & .112 & & & $2.088^{*}$ & .042 \\
\hline
\end{tabular}

Sumber: Data primer Diolah (2018)

Berdasarkan hasil analisis, persamaan regresi dapat dirumuskan $\mathrm{Y}=15,539+0,021 \mathrm{X} 1+0,149 \mathrm{X} 2+0,175$ $\mathrm{X} 3+0,065 \mathrm{X} 4$ (ns) $+0,145 \mathrm{X} 5$, dari persamaan tersebut menunjukkan terjadi pola hubungan positif variabel bebas yaitu bauran promosi yang terdiri atas biaya periklanan (X1), biaya promosi penjualan (X2), biaya penjualan perorangan (X3), biaya hubungan masyarakat (X4) dan biaya pemasaran langsung (X5).

\section{Analisis Uji F}

Hasil pengujian secara simultan menunjukkan $p \leq 0.05$, ini berarti ada pengaruh signifikan biaya bauran promosi terhadap omzet penjualan usaha agribisnis di Denpasar. Kontribusi dari biaya bauran promosi secara simultan berpengaruh signifikan terhadap omzet penjualan usaha agribisnis di Denpasar, dapat dilihat dari koefisien determinasi berganda (Adjusted $R$ Square) yaitu sebesar 0,575 atau $57,5 \%$ ini berarti bahwa variabel terikat (omzet penjualan) dapat dijelaskan oleh variabel bebas (biaya bauran promosi terdiri atas biaya periklanan, biaya promosi penjualan, biaya penjualan perorangan, hubungan masyarakat dan biaya pemasaran langsung dan sisanya $42,5 \%$ dijelaskan oleh variabel lain di luar variabel bebas yang digunakan.

\section{Analisis Uji t-test}

Secara parsial pengaruh biaya periklanan, biaya promosi penjualan, biaya penjualan perorangan, dan biaya pemasaran langsung secara parsial berpengaruh signifikan terhadap omzet penjualan usaha agribisnis di Denpasar dapat diketahui nilai thitung dari variabel periklanan 2,285 lebih besar dari tabel 1,663 $(\mathrm{df}=88-5=83, \alpha=$ 0,05 , dengan $p$-value (pada kolom sig) $0,018 p \leq$ 0.05 . Nilai thitung dari variabel promosi penjualan 2,906 besar dari ttabel $1,663(\mathrm{df}=88-5=83, \alpha=0.05$, dengan $p$-value (pada kolom sig) $0,002 p \leq 0,05$. Nilai thitung dari variabel penjualan perorangan 2.027 lebih besar dari ttabel 1,663 $(\mathrm{df}=88-5=83, \alpha=0.05$, dengan $p$-value (pada kolom sig) $0,043 p \leq 0.05$. Nilai thitung dari variabel biaya pemasaran langsung 2,088 lebih besar dari ttabel 1,663 $(\mathrm{df}=88-5=83, \alpha=0.05$, dengan $p$ value (pada kolom sig) $0,042 p \leq 0.05$. Secara parsial biaya hubungan masyarakat tidak signifikan diketahui dari nilai thitung dari variabel biaya hubungan masyarakat 0,833 lebih kecil dari tabel 1,663 $(\mathrm{df}=88-5=83, \alpha=0.05$, dengan $p$-value (pada kolom sig) $0,407 p \geq 0.05$.

\section{Standardized Coefficient Beta}

Hasil penelitian menunjukkan bahwa diantara kelima variabel bebas biaya promosi penjualan mempunyai pengaruh yang paling dominan terhadap omzet penjualan usaha agribisnis Denpasar. Hal ini dapat dapat dilihat dari nilai Standardized Coefficient Beta sebesar 0,463.

\section{SIMPULAN DAN SARAN}

\section{SIMPULAN}

Berdasarkan hasil analisis dan pembahasan yang telah dilakukan dalam penelitian ini, maka dapat diperoleh simpulan sebagai berikut: biaya bauran promosi yang terdiri atas biaya periklanan, biaya promosi penjualan, biaya penjualan perorangan, biaya hubungan masyarakat dan biaya pemasaran langsung secara simultan berpengaruh signifikan dengan $p \leq 0,05$ terhadap omzet penjualan pada usaha agribisnis di Denpasar. Besarnya pengaruh bauran promosi secara simultan sebesar 0,575 atau $57,5 \%$ sisanya $42,5 \%$ dipengaruhi oleh faktor lainnya; hasil analisis regresi linier berganda dapat diketahui bahwa biaya hubungan masyarakat secara parsial tidak signifikan dengan $p \geq 0,05$, tetapi biaya periklanan, biaya promosi penjualan, biaya penjualan perorangan dan biaya pemasaran langsung secara parsial berpengaruh signifikan dengan $p \leq 0,05$; dan hasil analisis regresi linier berganda dengan standardized Coefficient Beta dapat diketahui bahwa biaya promosipenjualan berpengaruh dominan terhadap omzet penjualan pada usaha agribisnis di Denpasar. 


\section{Saran}

Berdasarkan hasil analisis dan pembahasan yang telah dilakukan dalam penelitian ini, maka dapat diperoleh saran sebagai berikut: pengusaha agribisnis di Denpasar agar menerapkan biaya bauran promosi yang tepat dimasa mendatang sesuai dengan kemampuan dan anggaran yang dimiliki oleh perusahaan dan kelima biaya bauran promosi tetap dilakukan, namun harus memperhatikan dan mempertimbangkan pengalokasian dana secara efisien ke dalam biaya bauran promosi agar perusahaan tidak mengalami kerugian.

\section{DAFTAR PUSTAKA}

Anomin. 2018. Situs Resmi Binaan Dinas Koperasi UMKM Kota Denpasar. Tersedia di http://ukmdiskop.denpasarkot a.go.id/ (Diakses tanggal 25 februari 2018).

Badan Pusat Statistik Kota Denpasar Tahun. 2013. Data Sensus Pertanian Tersedia di Http://st2013.bps.go.id (Diakses tanggal 14 Juli 2018).

Dane, N. 2013. Analisis Pengaruh Biaya Promosi Terhadap Nilai Penjualan Produk pada UD. KopiBayuatis, Singaraja. (Tesis). Denpasar: Universitas Udayana, Program Pascasarjana.

Hasan, I. 2002. Metodologi Penelitian dan Aplikasinya. Jakarta: Ghalia Indonesia.

Kotler P., dan Armstrong. 2012. Manajemen Pemasaran. Edisi XI. Jakarta : Salemba Empat

Sugiyono. 2015. Metode Penelitian Kuantitatif Kualitatif dan R\&D. Bandung: Alfabeta

Swastha, B., dan Irawan. 2008. Manajemen Pemasaran Modern. Yogyakarta: Liberty.

Widarjono, A. 2015. Analisis Multivariat Terapan. Yogyakarta: UPP STIM YKPN. Edisi II, April 2015. 